\title{
ZASTUPANJE STRANKE U UPRAVNOM SPORU
}

Lidija Rostaš-Beroš, sutkinja

Visoki upravni sud Republike Hrvatske
UDK: 35.077 .2

Ur.: 15. siječnja 2016.

Pr.: 8. ožujka 2016.

Stručni rad

\begin{abstract}
Sažetak
U ovom radu razmatra se tko sve može sudjelovati kao stranka u upravnom sporu. Ukazuje se koje osobe mogu u ime stranaka poduzimati radnje u postupku te koje su osobe ovlaštene za zastupanje tužitelja i zainteresirane osobe, kao i na pitanja valjanosti zastupanja stranaka u upravnosudskom te u parničnom postupku koji se u upravnom sporu primjenjuje na odgovarajući način.
\end{abstract}

Ključne riječi: upravni spor, stranka, zastupanje, parnični postupak, postupovna sposobnost, poslovna sposobnost.

\section{UVODNE NAPOMENE}

U ovom radu autorica je razmatrala dio upravnosudskog postupka koji se odnosi na stranke u upravnom sporu i njihovo zastupanje. U prvom dijelu se iznosi koje stranke mogu sudjelovati u sporu te, tko sve može biti tužitelj i tuženik, a tko zainteresirana osoba dodajući pritom i položaj jedinica lokalne i područne (regionalne) samouprave kao stranaka u sporu.

Zatim se izlaže tko je ovlašten poduzimati radnje za tužitelja i zainteresiranu osobu, a tko za tuženika nakon zadnjih zakonskih intervencija. Iznosi se koja svojstva treba imati postupovno sposobna osoba, s posebnim osvrtom na propisanu odgovarajuću primjenu odredbi parničnog postupka kojima je uređena poslovna sposobnost fizičke osobe.

Nadalje se iznosi tko je sve ovlašten zastupati tužitelja i zainteresiranu osobu u sporu, posebice nakon izmjena i dopuna zakonskog uređenja koje na pitanja valjanosti zastupanja koja nisu uređena Zakonom o upravnim sporovima ${ }^{1}$ upućuju na odgovarajuću primjenu odredaba kojima je uređeno zastupanje u parničnom postupku. Pobliže se iznose i odredbe parničnog postupka kojima je uređeno zastupanje stranaka u tom postupku.

1 Zakon o upravnim sporovima, Narodne novine, br. 20/10., 143/12. i 152/14. - dalje u tekstu: ZUS. 


\section{TKO SU STRANKE U UPRAVNOM SPORU}

Stranke u upravnom sporu su tužitelj, tuženik i zainteresirana osoba. ${ }^{2}$

\subsection{Tužitelj}

Odredba članka 17. ZUS-a propisuje tko može biti tužitelj u upravnom sporu.

a) U upravnom sporu tužitelj je fizička ili pravna osoba koja smatra da su joj povrijeđena prava i pravni interesi pojedinačnom odlukom, postupanjem javnopravnog tijela, odnosno propuštanjem donošenja pojedinačne odluke ili postupanja javnopravnog tijela u zakonom propisanom roku ili sklapanjem, raskidom ili izvršavanjem upravnog ugovora.

Dakle, svaka osoba koja smatra da su joj prava i pravni interesi povrijeđeni bilo kojom radnjom koja može biti predmet upravnog spora ima pravo tužbom pokrenuti upravni spor te steći položaj tužitelja. ${ }^{3}$

b) Zatim tužitelj može biti i osoba koja nema pravne osobnosti ili skupina osoba ako su pojedinačnom odlukom ili postupanjem javnopravnog tijela povrijeđena njihova prava i pravni interesi.

Dakle, položaj tužitelja u upravnom sporu ne vezuje se usko uz pravnu sposobnost, tj. svojstvo fizičke ili pravne osobe, već uz stranačku sposobnost neke osobe, tj. mogućnost biti nositeljem prava i obveza u nekoj upravnoj stvari. ${ }^{4}$

c) Tužitelj može biti javnopravno tijelo koje je sudjelovalo ili je trebalo sudjelovati u donošenju odluke, postupanju ili sklapanju upravnog ugovora.

Kada se radi o jedinicama lokalne i područne (regionalne) samouprave valja navesti da su one pravne osobe i da mogu biti tužitelji u upravnom sporu, ali tijela jedinica lokalne i područne (regionalne) samouprave nisu pravne osobe i ne mogu biti nositelji prava i obveza, stoga u pravilu ne mogu biti ni tužitelji u upravnom sporu.

Iznimno ta tijela mogu imati položaj tužitelja $\mathrm{i}$ to u situaciji u kojoj su u donošenju pojedinačne odluke (upravnog akta) postupanju ili sklapanju upravnog ugovora trebala sudjelovati dva javnopravna tijela, od kojih je jedno tijelo jedinice lokalne i područne (regionalne) samouprave. No odluku je donijelo samo ono drugo javnopravno tijelo bez suradnje tijela jedinice lokalne i područne (regionalne) samouprave. Jednaka je situacija i kad su dva javnopravna tijela trebala postupiti ili sklapati upravni ugovor surađujući, a propisane suradnje nije bilo. Za ocjenu same tužbovne legitimacije tijela lokalne i područne (regionalne) samouprave irelevantan je razlog izostanka suradnje. ${ }^{5}$

2 Čl. 16. ZUS-a.

3 Đerđa, D. i Šikić, M., Komentar Zakona o upravnim sporovima, Novi informator, Zagreb, 2012., str. 131.

4 Ibid., str. 132.

5 Medvedović, D., Jedinice lokalne i područne (regionalne) samouprave - primjena ZUS-a, propisa o financiranju jedinica i preoblikovanje trgovačkih društava u djelatnosti vode $\mathrm{i}$ odvodnje, Novi informator, Zagreb, 2012., str. 19. 
d) Tužitelj može biti i državno tijelo ovlašteno zakonom. Ovdje je bitno da se radi o državnom tijelu i da ovlaštenje za podnošenje upravne tužbe proizlazi iz zakona.

Koje će državno tijelo biti ovlašteno podnijeti tužbu, ovisi o zakonima kojima se uređuje nadležnost pojedinih tijela, kao što su primjerice zakoni kojima se uređuje nadležnost državnog odvjetništva, pučkog pravobranitelja, drugih pravobranitelja itd., ili zakonima kojima se uređuje neko posebno upravno područje. ${ }^{6}$

\subsection{Tuženik}

Tko može biti tuženik u upravnom sporu, uređuje članak 18. ZUS-a.

Tako ZUS propisuje da je tuženik javnopravno tijelo koje je donijelo ili propustilo donijeti pojedinačnu odluku, postupilo ili propustilo postupiti, odnosno koje je stranka upravnog ugovora.

Tuženik je najčešće drugostupanjsko javnopravno tijelo koje je odlučivalo o žalbi ili prigovoru izjavljenom protiv odluke prvostupanjskog tijela. Međutim, u slučaju kada je zakonom propisano da protiv odluke prvostupanjskog javnopravnog tijela nije dopušteno izjaviti redoviti pravni lijek, već se može pokrenuti upravni spor, tuženik je prvostupanjsko javnopravno tijelo koje je donijelo ili propustilo donijeti odluku, postupilo ili propustilo postupiti.

Dakle, tuženik u upravnom sporu je uvijek javnopravno tijelo, a javnopravnim tijelom se u smislu ZUS-a smatra tijelo državne uprave i drugo državno tijelo, tijelo jedinice lokalne i područne (regionalne) samouprave, pravna osoba koja ima javnu ovlast i pravna osoba koja obavlja javnu službu (pružatelj javnih usluga). ${ }^{7}$

Jedinica lokalne i područne (regionalne) samouprave nema, prema odredbi članka 18. ZUS-a, položaj tuženika. Međutim, posebnim se zakonom može jedinicama lokalne i područne (regionalne) samouprave u nekim upravnim stvarima ili u svezi s nekim pojedinačnim odlukama priznati položaj tuženika. ${ }^{8}$

\subsection{Zainteresirana osoba}

Položaj zainteresirane osobe u upravnom sporu reguliran je odredbom članka 19. ZUS-a.

Tako je propisano da je zainteresirana osoba svaka osoba kojoj bi poništavanje, izmjena ili donošenje pojedinačne odluke, postupanje ili propuštanje postupanja javnopravnog tijela, odnosno sklapanje, raskid ili izvršavanje upravnog ugovora povrijedilo njezino pravo ili pravni interes. Zainteresirana osoba je i javnopravno tijelo koje smatra da sudska odluka može imati učinak na prava i pravne interese koje to javnopravno tijelo štiti na temelju zakona.

6 Đerđa, Šikić, op. cit. (bilj. 3.), str. 133.

7 Čl. 2. st. 2. ZUS-a.

8 Medvedović, D., op. cit. (bilj. 5.), str. 20. 
Dakle, nije to umješač u upravnom sporu, već stranka koje se neposredno tiče predmet upravnog spora. Zainteresirana osoba ne može sama pokrenuti upravni spor, već se može pojaviti u upravnom sporu koji se vodi. U upravnom sporu može biti i više zainteresiranih osoba, što ovisi o tome o kakvom se upravnom predmetu radi. ${ }^{9}$

Naime, umješač u parničnom postupku je osoba koja ima pravni interes da u parnici koja teče među drugim osobama (strankama) jedna od stranaka uspije i koja se može pridružiti toj stranci. ${ }^{10}$ Dakle, za razliku od zainteresirane osobe u upravnom sporu koja jest stranka u postupku, umješač nije stranka u postupku, a pravni interes da sudjeluje u tuđoj parnici ima stoga što se pravne posljedice donesene presude mogu posredno odraziti i na njegovu pravnu situaciju.

U upravnom sporu zainteresirana osoba može se javiti kako na strani tuženika tako i na strani tužitelja, što znači da njezin interes u sporu unaprijed nije određen. ${ }^{11}$

Položaj zainteresirane osobe u upravnom sporu načelno mogu imati i jedinice lokalne i područne (regionalne) samouprave i tijela tih jedinica. ${ }^{12}$

Bilo po službenoj dužnosti ili na prijedlog stranke, sud će zainteresiranu osobu pozvati da sudjeluje u sporu. ZUS propisuje da se zainteresirana osoba u spor može uključiti u svakom trenutku, o čemu je sud dužan obavijestiti sve stranke u sporu. ${ }^{13}$

Ovdje treba napomenuti da se proširenjem predmeta upravnog spora (čl. 3 . ZUS-a) proširio i krug zainteresiranih osoba u sporu te je, stoga, radi poštovanja načela učinkovitosti i ekonomičnosti važno već na početku upravnog spora utvrditi tko su zainteresirane osobe u konkretnom sporu. Na taj bi se način izbjeglo eventualno ponavljanje radnji u sporu provedenih prije uključivanja zainteresiranih osoba u spor.

\section{TKO MOŽE PODUZIMATI RADNJE ZA STRANKU}

\subsection{Poduzimanje radnji za tužitelja i zainteresiranu osobu}

Za utvrđivanje pretpostavki za poduzimanje postupovnih radnji važno je poduzima li te radnje fizička osoba kao stranka u sporu, koja u pravilu može samostalno poduzimati radnje, ili pravna osoba, osoba koja nema pravnu osobnost, odnosno skupina osoba, u ime i za račun kojih radnje u sporu uvijek poduzima zakonski zastupnik odnosno ovlašteni predstavnik. ${ }^{14}$

9 Krijan, P., Komentar Zakona o upravnim sporovima, Informator, Zagreb, 2001., str. 8.

10 Čl. 206. do 209.a Zakona o parničnom postupku, Narodne novine, br. 53/91., 91/92., 112/99., 88/01., 117/03., 88/05., 2/07., 84/08., 96/08., 123/08., 57/11. i 148/11. - pročišćeni tekst, 25/13., dalje u tekstu: ZPP.

11 Đerđa, Šikić, op. cit. (bilj. 3.), str. 142.

12 Medvedović, D., loc. cit.

13 Čl. 19. st. 3., 4. i 5. ZUS-a.

14 Đerđa, Šikić, op. cit. (bilj. 3.), str. 145. 
Svojstvo određene osobe da poduzima postupovne radnje u sporu (pokretanje spora, sudjelovanje u raspravi, predlaganje dokaza, izjavljivanje pravnih lijekova) predstavlja postupovnu sposobnost te osobe.

ZUS propisuje da tužitelj i zainteresirana osoba mogu poduzimati radnje u sporu ako su potpuno poslovno sposobni, odnosno u granicama svoje poslovne sposobnosti. Za tužitelja ili zainteresiranu osobu radnje u sporu može poduzimati osoba ovlaštena za zastupanje, zajednički predstavnik i zajednički opunomoćenik skupine osoba. ${ }^{15}$

Postupovnu sposobnost imaju sve osobe kojima poslovna sposobnost nije ograničena, a osobe kojima je poslovna sposobnost djelomično ograničena, postupovno su sposobne u granicama svoje poslovne sposobnosti. Osobe kojima je poslovna sposobnost potpuno oduzeta nemaju postupovnu sposobnost, već za njih radnje u postupku poduzimaju njihovi zakonski zastupnici.

Poslovnu sposobnost imaju fizičke i pravne osobe. Na pitanje poslovne sposobnosti fizičke osobe ZUS upućuje na odgovarajuću primjenu odredaba kojima je uređena poslovna sposobnost fizičke osobe u parničnom postupku. ${ }^{16}$

Poslovna sposobnost je svojstvo određene osobe da može vlastitim očitovanjima volje stvarati pravne učinke. Fizička osoba stječe poslovnu sposobnost punoljetnošću, a pravna danom nastanka, ako zakonom nije drukčije određeno. Osoba koja nije punoljetna može stvarati samo pravne učinke određene zakonom. Umjesto osobe koja nema poslovnu sposobnost očitovat će svoju volju njezin zakonski zastupnik ili skrbnik, a za pravnu osobu volju očituju njezina tijela u pravnim poslovima i postupcima koje poduzimaju u tome svojstvu. ${ }^{17}$

Stjecanje poslovne sposobnosti fizičke osobe regulirano je odredbom članka 117. Obiteljskog zakona ${ }^{18}$ koji propisuje da dijete potpunu poslovnu sposobnost stječe punoljetnošću ili sklapanjem braka prije punoljetnosti, a da je punoljetna osoba koja je navršila osamnaest godina života.

Dakle, svaka punoljetna osoba ili osoba koja je sklopila brak prije punoljetnosti, poslovno i postupovno je sposobna te može samostalno u ulozi tužitelja ili zainteresirane osobe poduzimati radnje u upravnom sporu. Međutim, svaka postupovno sposobna osoba ne mora biti istodobno i potpuno poslovno sposobna, već to može biti i osoba kojoj je poslovna sposobnost djelomično ograničena u kojem slučaju radnje u sporu može poduzimati samo u granicama svoje poslovne sposobnosti.

Osoba kojoj je poslovna sposobnost djelomično ograničena je osoba koja je nakon punoljetnosti djelomično lišena poslovne sposobnosti i maloljetnik $\mathrm{s}$ navršenih 15 godina života koji stupi u radni odnos. Takav maloljetnik može samostalno poduzimati pravne radnje, odnosno sklapati pravne poslove i preuzimati

15 Čl. 20. st. 1. i 2. ZUS-a.

16 Čl. 20. st. 6. ZUS-a.

17 Čl. 18. Zakona o obveznim odnosima, Narodne novine, br. 35/05., 41/08., 125/11. i 78/15., dalje u tekstu: ZOO.

18 Obiteljski zakon, Narodne novine, br. 103/15., dalje u tekstu: OZ. 
obveze u visini iznosa koji zarađuje te raspolagati svojom zaradom pod uvjetom da ne ugrožava svoje uzdržavanje. ${ }^{19}$

Punoljetnu osobu koja se zbog duševnih smetnji ili drugih razloga nije sposobna brinuti o nekom od svojih prava potreba ili interesa, ili koja ugrožava prava i interese drugih osoba o kojima je dužna skrbiti se, sud će u tom dijelu lišiti poslovne sposobnosti. Takva osoba ne može biti potpuno lišena poslovne sposobnosti. Rješenjem o lišenju poslovne sposobnosti sud određuje radnje i poslove koje osoba nije sposobna samostalno poduzeti u odnosu na osobno stanje te imovinu. To su na primjer odluke koje se odnose na davanje izjava ili poduzimanje radnji koje se odnose na promjenu osobnog imena, sklapanje i prestanak braka, roditeljstvo, donošenje odluke o zdravlju, mjestu prebivališta, odnosno boravišta, zapošljavanju i drugo, osim ako zakonom nije drukčije određeno. Radnje i poslovi koje osoba nije sposobna samostalno poduzeti i koji se odnose na imovinu su raspolaganje i upravljanje imovinom, plaćom ili drugim stalnim novčanim primanjima, osim ako zakonom nije drukčije određeno. Za poslove koji nisu određeni u odluci o djelomičnom lišenju poslovne sposobnosti osoba lišena poslovne sposobnosti ima poslovnu sposobnost te ih može samostalno poduzimati. ${ }^{20}$

\subsection{Poduzimanje radnji za tuženika}

Odredba članka 20. stavka 3. ZUS-a propisuje da za tuženika u sporu, koji je uvijek javnopravno tijelo, radnje može poduzimati u prvom redu službena osoba javnopravnog tijela koja je donijela ili propustila donijeti odluku, postupila ili propustila postupiti te druga osoba određena propisima o unutarnjem ustrojstvu javnopravnog tijela.

Nadalje, radnje u sporu za tuženika može poduzimati i službena osoba javnopravnog tijela čija je odluka potvrđena osporavanom odlukom te druga osoba određena propisima o unutarnjem ustrojstvu javnopravnog tijela.

Naime, zadnjim izmjenama i dopunama Zakona o upravnim sporovima (Narodne novine br. 20/10. i 143/12.) iz prosinca 2014. ${ }^{21}$ za poduzimanje radnji u sporu za tuženika dano je ovlaštenje i službenoj osobi prvostupanjskog tijela čija je odluka potvrđena tuženikovom odlukom.

U Obrazloženju Konačnog prijedloga zakona o izmjenama i dopunama Zakona o upravnim sporovima navedeno je sljedeće: „Normiranim rješenjem doprinijet će se poštivanju načela učinkovitosti budući da će se troškovi postupka (ponajprije putni troškovi), s obzirom na manju prostornu udaljenost ovih tijela od sjedišta suda, bitno smanjiti, a također će se i skratiti trajanje spora, budući da će se skratiti vrijeme potrebno za dostavu podnesaka i akata, kao i rokovi u kojima se može zakazati rasprava te rokovi za očitovanje na navode protivne stranke. Pritom će se

19 Čl. 85. OZ-a.

20 Čl. 234. OZ-a.

21 Zakon o izmjenama i dopunama Zakona o upravnim sporovima, Narodne novine, br. 152/14., dalje u tekstu: ZIDZUS. 
također doprinijeti kvaliteti upravnog spora, budući da je u predmetima u kojima je drugostupanjska odluka potvrđena prvostupanjskom odlukom sve dokazne radnje u pravilu provelo upravo prvostupanjsko tijelo, koje samim tim ima i najviše saznanja o predmetu u kojem je donesena osporavana odluka, a smanjit će se i opterećenje na drugostupanjsko tijelo koje je donijelo osporavanu odluku, naročito imajući u vidu činjenicu nedostatnih kapaciteta tih tijela." ${ }^{\prime 22}$

Osim navedenoga, za poduzimanje radnji u sporu čelnik tijela može ovlastiti i drugu službenu osobu javnopravnog tijela.

Odredbe o ovlasti za poduzimanje radnji tuženika u upravnom sporu su kogentne naravi, s time da ipak tuženiku dopuštaju izbor između nekoliko mogućnosti od kojih su neke doista široke. No, tuženik ne može izabrati ni jedan drugi način za poduzimanje radnji u sporu. ${ }^{23}$

Iznimno, tijela državne uprave i druga državna tijela po punomoći čelnika može zastupati državno odvjetništvo. ${ }^{24}$

Dakle, tuženo javnopravno tijelo s iznimkom tijela državne uprave i drugih državnih tijela, trebaju zastupati isključivo zaposlenici toga tijela te se ono za zastupanje u ulozi tuženika ne može služiti uslugama odvjetnika. ${ }^{25} \mathrm{U}$ propisanim slučajevima tuženika mogu zastupati i službene osobe prvostupanjskog tijela.

\section{ZASTUPANJE TUŽITELJA I ZAINTERESIRANE OSOBE}

Tužitelj i zainteresirana osoba nisu dužni sami poduzimati radnje u upravnom sporu, a neki od njih to nisu niti u stanju učiniti. Umjesto njih radnje u sporu poduzimaju osobe koje su ovlaštene zastupati ih i takve radnje imaju isti pravni učinak kao da ih je poduzela sama stranka. Međutim, sud može, kada to smatra korisnim za razrješenje spora, pozvati tužitelja ili zainteresiranu osobu koje zastupa osoba ovlaštena za zastupanje da se osobno odazovu i izjasne o određenim činjenicama. ${ }^{26}$ Ovim pravom sud se može koristiti samo radi utvrđivanja činjenica, ali ne pozivajući se na nj inzistirati na zaštiti prava i pravnih interesa stranke, jer prava i pravne interese stranke u upravnom sporu može štititi i osoba ovlaštena za zastupanje stranke. ${ }^{27}$

Osoba ovlaštena za zastupanje tužitelja i zainteresirane osobe u sporu je zakonski zastupnik, zajednički predstavnik i opunomoćenik. Takva osoba je dužna

22 Mrežna stranica: http/www.sabor.hr, 15. sjednica Hrvatskog sabora održana 12. prosinca 2014.

23 Medvedović, D., op. cit. (bilj. 5.), str. 24.

24 O ustrojstvu i nadležnosti državnih odvjetništava vidi: Zakonu o državnom odvjetništvu, Narodne novine, br. 76/09., 153/09., 116/10., 145/10., 57/11., 130/11., 72/13., 148/13., 33/15. i $82 / 15$.

25 Đerđa, Šikić, op. cit. (bilj. 3.), str. 147.

26 Čl. 20. st. 4. i 5. ZUS-a.

27 Đerđa, Šikić, op. cit. (bilj. 3.), str. 148. 
pri prvoj radnji u sporu podnijeti dokaz o ovlasti za zastupanje stranke, ${ }^{28}$ dakle dužna je pri poduzimanju prve postupovne radnje u ime stranke dokazati svoju legitimaciju za to.

Na pitanja valjanosti zastupanja koja nisu uređena ZUS-om na odgovarajući način se primjenjuju odredbe kojima je uređeno zastupanje u parničnom postupku. ${ }^{29}$

U parničnom postupku stranka može nastupati samostalno ili putem svog zakonskog zastupnika ili opunomoćenika. Jednako kao u upravnom postupku i sporu, stranka može radnje u postupku poduzimati osobno ili putem svog opunomoćenika, s tim da stranku koja nema parničnu sposobnost zastupa njezin zakonski zastupnik. ${ }^{30}$

Stranka koja je parnično sposobna ovlaštena je da samostalno odluči hoće li sama djelovati u parnici ili će nekog drugog ovlastiti da to učini u njeno ime i za njezin račun. Ona sa svojim zastupnikom zaključuje ugovor o zastupanju. Ugovorni i dobrovoljni zastupnici - punomoćnici - crpe svoja ovlaštenja iz volje stranke. Nasuprot tome, stranke koje nisu poslovno i parnično sposobne, odnosno koje zbog drugih razloga nisu u mogućnosti da same postupaju pred sudom ili da u tu svrhu imenuju punomoćnika, zastupaju pred sudom nužni ili zakonski zastupnici koji svoja ovlaštenja crpe neposredno iz zakona. ${ }^{31}$

\subsection{Zakonski zastupnik}

Zakonski zastupnik je fizička poslovno i postupovno sposobna osoba koja je ovlaštena zastupati onu stranku u sporu (fizičku ili pravnu osobu) koja nema postupovnu sposobnost. ${ }^{32}$ Zakonski zastupnik određuje se zakonom ili aktom nadležnoga državnog tijela donesenim na temelju zakona. ${ }^{33}$

Zakon o parničnom postupku propisuje da zakonski zastupnik može u ime stranke poduzimati sve radnje u postupku. Ako je za poduzimanje pojedinih radnji u postupku posebnim propisima određeno da zastupnik mora imati posebno ovlaštenje, on može te radnje poduzimati samo ako ima takvo ovlaštenje, što je dužan i dokazati. Kad sud utvrdi da zakonski zastupnik osobe pod skrbništvom ne pokazuje potrebnu pažnju u zastupanju, obavijestit će o tome centar za socijalnu skrb. Ako bi zbog propuštanja zastupnika mogla nastati šteta za osobu pod skrbništvom, sud će zastati s postupkom i predložiti da se odredi drugi zakonski

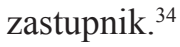

28 Čl. 21. st. 1. ZUS-a.

29 Čl. 21. st. 2. ZUS-a.

30 Jelinić, Z., Zastupanje stranaka u parničnim i upravnim postupcima i sporu - potreba za osiguranjem sustavnog i jedinstvenog pristupa materiji zastupanja, Pravni vijesnik god. 28 br. 1, 2012., str. 63.

31 Triva, S., Dika, M., Građansko parnično procesno pravo, Narodne novine, Zagreb, 2004., str. 318.

32 Zakonski zastupnici - vidjeti čl. 92., 99. do 101. te čl. 218. do 269. OZ-a.

33 Čl. 80. ZPP-a.

34 Čl. 81. ZPP-a 
Nadalje isti zakon propisuje obvezu suda da tijekom cijelog postupka, po službenoj dužnosti, pazi može li osoba koja se pojavljuje kao stranka biti stranka u postupku i je li parnično sposobna, zastupa li parnično nesposobnu stranku njezin zakonski zastupnik i ima li zakonski zastupnik posebno ovlaštenje kad je ono potrebno. ${ }^{35}$

Kad sud utvrdi da osoba koja se pojavljuje kao stranka ne može biti stranka u postupku, a taj se nedostatak može otkloniti, pozvat će tužitelja da izvrši potrebne ispravke u tužbi ili će poduzeti druge mjere da bi se postupak mogao nastaviti s osobom koja može biti stranka u postupku.

Isto tako, kad sud utvrdi da stranka nema zakonskog zastupnika ili da zakonski zastupnik nema posebno ovlaštenje kad je ono potrebno, zatražit će da nadležni centar za socijalnu skrb postavi skrbnika parnično nesposobnoj osobi odnosno pozvat će zakonskog zastupnika da pribavi posebno ovlaštenje ili će poduzeti druge mjere koje su potrebne da bi parnično nesposobna stranka bila pravilno zastupana. Sud može odrediti stranci rok za otklanjanje navedenih nedostataka.

Dok se ne otklone ti nedostaci, u postupku se mogu poduzimati samo one radnje zbog čije bi odgode mogle nastati štetne posljedice za stranku.

Ako se navedeni nedostaci ne mogu otkloniti ili ako određeni rok bezuspješno protekne, sud će rješenjem ukinuti radnje provedene u postupku ako su zahvaćene tim nedostacima i odbaciti tužbu ako su nedostaci takve prirode da sprečavaju daljnje vođenje postupka. ${ }^{36}$

Pravnu osobu uvijek zastupa zakonski zastupnik ili ovlašteni predstavnik. Zakonski zastupnik pravne osobe određen je zakonom, dok je ovlašteni predstavnik određen općim aktom te pravne osobe. ${ }^{37}$

Kad jedinica lokalne i područne (regionalne) samouprave sudjeluje u upravnom sporu kao tužitelj ili zainteresirana osoba, nju zastupa njen zakonski zastupnik. Prema odredbi članka 42. ZOLIPS-a, ${ }^{38}$ zakonski zastupnik općine, grada i županije je općinski načelnik, gradonačelnik odnosno župan. Oni su, dakle, zakonski zastupnici ex lege. Nema zapreke da općinski načelnik, gradonačelnik ili župan opunomoći odvjetnika za poduzimanje radnji u upravnom sporu. ${ }^{39}$

\subsection{Zajednički predstavnik}

Kad u upravnom sporu kao tužitelj ili zainteresirana osoba sudjeluje skupina osoba koja smatra da su pojedinačnom odlukom ili postupanjem javnopravnog tijela povrijeđena njihova prava i pravni interesi, tada takvu skupinu predstavlja zajednički predstavnik ili zajednički opunomoćenik. Naime, članovi takve skupine

35 Čl. 82. ZPP-a.

36 Čl. 83. ZPP-a.

37 Đerđa, Šikić, op. cit. (bilj. 3.), str. 149.

38 Zakon o lokalnoj i područnoj (regionalnoj) samoupravi, Narodne novine, br. 33/01., 60/01., 129/05., 109/07., 125/08., 36/09., 150/11., 144/12. i 19/13. - pročišćeni tekst.

39 Medvedović, D., op. cit. (bilj. 5.), str. 22. 
mogu između sebe odrediti osobu koja će ih zastupati tj. odrediti predstavnika skupine ili mogu opunomoćiti odvjetnika da kao stručna osoba poduzima radnje u sporu u njihovo ime.

\subsection{Opunomoćenik}

\subsubsection{Punomoć}

Punomoć je ovlaštenje za zastupanje što ga opunomoćitelj pravnim poslom daje opunomoćeniku. ${ }^{40}$ Naime, punomoć predstavlja sredstvo na osnovu kojeg odvjetnik, odnosno druga osoba koja nije odvjetnik - „običan“ punomoćnik može djelovati u ime i za račun stranke što znači da će radnje koje poduzme punomoćnik imati isti pravni učinak kao da ih je poduzela sama stranka. U praksi, punomoć dana odvjetniku predstavlja najčešći temelj na kojem počiva ovlast za zastupanje iako naše pravo, neovisno o tome je li riječ o upravnom sporu ili postupku, odnosno parničnom postupku ne priječi procesno poslovno sposobne stranke da u okviru procesne kategorije postulacijske sposobnosti ${ }^{41}$ same, bez asistencije punomoćnika, poduzimaju radnje u postupcima u kojima imaju svojstvo stranke. ${ }^{42}$

Zastupanje po punomoćnicima svoju pravnu osnovu nalazi u Zakonu o obveznim odnosima. Riječ je o podjeli ovlasti na sklapanje ugovora i drugih pravnih poslova uključujući i poduzimanje pravnih radnji u ime i za račun zastupanoga $\mathrm{s}$ tim da se pravni učinak poduzete radnje ili sklopljenog posla proteže izravno na zastupanoga. ${ }^{43}$

\subsubsection{Tko može biti opunomoćenik}

Prije zadnjih izmjena i dopuna iz prosinca 2014. Zakon o upravnim sporovima (članak 21.) samo je propisivao tko sve može zastupati tužitelja i zainteresiranu osobu. Dakle, nije bilo ograničenja u pogledu osobe koju su tužitelj i zainteresirana osoba mogli opunomoćiti da ih zastupa u sporu. Stoga ih je mogla zastupati svaka poslovno sposobna osoba, osim osobe koja bi se pružanjem pravne pomoći uz naplatu bavila neovlašteno, tj. koja bi se bavila nadripisarstvom. ${ }^{44}$

Kako odredbe članka 21. do tada važećeg Zakona nisu regulirale procesni alat za ocjenu valjanosti zastupanja stranke u upravnom sporu, taj problem je riješen pozivom na odgovarajuću primjenu pravila parničnog postupka ${ }^{45}$

40 Čl. 313. st. 1. ZOO-a.

41 Postulacijska sposobnost je svojstvo parnično sposobne osobe da može bez punomoćnika sama neposredno poduzimati parnične radnje pred sudom s procesnopravnim učinkom, v. Triva, Dika, op. cit. (bilj. 31.), str. 311.

42 Jelinić, Z., op. cit. (bilj. 30.), str. 58.

43 Ibid., str. 63.

44 Nadripisarstvo predstavlja kazneno djelo protiv pravosuđa, čl. 313. Kaznenog zakona, Narodne novine, br. 125/11., 144/12., 56/15. i 61/15.

45 Obrazloženje čl. 5. Konačnog prijedloga ZIDZUS-a, op. cit. (bilj. 22.). 
Nakon spomenutih izmjena i dopuna ZUS-a mijenja se mogućnost odabira opunomoćenika jer u parničnom postupku stranku kao punomoćnik može zastupati samo odvjetnik, ako zakonom nije drukčije određeno. Zakonom o parničnom postupku je određeno da osim odvjetnika stranku kao punomoćnik može zastupati i osoba koja je s njom u radnom odnosu, ako je potpuno poslovno sposobna, zatim srodnik po krvi u pravoj liniji (do bilo kojeg stupnja), brat, sestra ili bračni drug ako je potpuno poslovno sposoban i ako se ne bavi nadripisarstvom. ${ }^{46}$

Ako se kao punomoćnik pojavi osoba koja prema navedenim mjerilima to ne može biti, sud će takvoj osobi uskratiti daljnje zastupanje i o tome obavijestiti stranku. U parničnom postupku je protiv rješenja o uskrati zastupanja dopuštena žalba koja ne zadržava provedbu rješenja. A ako sud utvrdi da punomoćnik koji nije odvjetnik nije sposoban obavljati tu dužnost, upozorit će stranku na štetne posljedice koje mogu nastati zbog nepravilnog zastupanja. ${ }^{47}$

U praksi Visokog upravnog suda Republike Hrvatske zabilježen je slučaj u kojem je tužitelj za pokretanje i vođenje upravnog spora opunomoćio osobu koja nije odvjetnik i koja ne spada u propisane iznimke. Upravni sud je toj osobi uskratio zastupanje i o tome obavijestio stranku. Opunomoćena osoba je primjenom odredbi ZPP-a, u ime tužitelja podnijela žalbu Visokom upravnom sudu. Visoki upravni sud je rješenjem ${ }^{48}$ žalbu odbacio kao nedopuštenu uz obrazloženje da je prvostupanjski sud pravilno primjenio odredbe ZPP-a koji se na odgovarajući način primjenjuje samo na pitanja valjanosti zastupanja koja nisu uređena ZUS-om. Kako je pitanje dopuštenosti žalbe protiv rješenja u upravnom sporu uređeno ZUS-om, Visoki upravni sud je prema pravilima ZUS-a odbacio žalbu kao nedopuštenu, bez obzira što je u parničnom postupku protiv rješenja o uskrati zastupanja žalba dopuštena. ${ }^{49}$

Naime, pravila parničnog postupka se u upravnom sporu primjenjuju na odgovarajući način, uvažavajući pritom strukturu i različitost upravnog spora, a ne doslovno kako je to protumačila osoba kojoj je uskraćeno zastupanje.

Uz to valja imati na umu da se odredbe kojima je uređeno zastupanje u parničnom postupku ne mogu primjenjivati na zastupanje svih stranaka u sporu kao u parničnom postupku, već samo na zastupanje tužitelja i zainteresirane osobe. Naime, u praksi su zabilježeni slučajevi u kojima je upravni sud odvjetniku uskratio zastupanje tuženika jer ZUS-om nije propisana mogućnost da tuženika u upravnom sporu zastupa odvjetnik. Dakle, kod primjene odredbi kojima je uređeno zastupanje u parničnom postupku treba voditi računa o specifičnosti upravnog spora u odnosu na parnični postupak i u tom smislu na odgovarajući način primjeniti odredbe parničnog postupka pod uvjetom da takvu mogućnost propisuje zakon kojim je uređen upravni spor.

46 Čl. 89.a ZPP-a.

47 Čl. 90. ZPP-a.

48 Rješenje poslovni broj: Usž-2483/15-2 od 26. veljače 2015.

49 Žalba protiv rješenja prvostupanjskog suda u parničnom postupku je dopuštena ako u ZPP-u nije određeno da žalba nije dopuštena (čl. 378. st. 1. ZPP-a), dok se žalba protiv rješenja upravnog suda može podnijeti samo kad je to propisano ZUS-om (čl. 67. st. 1. ZUS-a). 
Ako se kao punomoćnik pojavi osoba koja prema navedenim mjerilima to ne može biti, sud će takvoj osobi uskratiti daljnje zastupanje i o tome obavijestiti stranku. A ako sud utvrdi da punomoćnik koji nije odvjetnik nije sposoban obavljati tu dužnost, upozorit će stranku na štetne posljedice koje mogu nastati zbog nepravilnog zastupanja. ${ }^{50}$

Ako u parnicama o imovinskopravnim zahtjevima vrijednost predmeta spora prelazi 50.000,00 kuna, punomoćnici pravnih osoba mogu biti samo osobe koje imaju položen pravosudni ispit. ${ }^{51} \mathrm{U}$ parničnom postupku, povreda ove zakonske odredbe spada u relativno bitne povrede odredaba parničnog postupka.

Kako se na valjanost zastupanja u upravnom sporu na odgovarajući način primjenjuju odredbe parničnog postupka, to proizlazi da u imovinskopravnim sporovima (npr. izvlaštenje, povrat imovine oduzete za vrijeme komunističke vladavine) u kojima vrijednost predmeta spora prelazi 50.000,00 kuna, opunomoćenik pravne osobe treba imati položen pravosudni ispit. Međutim, ako upravni sud u tijekom spora ne bi pravilno primijenio tu zakonsku odredbu, radilo bi se o takvoj povredi pravila sudskog postupka koja ne bi utjecala na donošenje zakonite i pravilne presude. ${ }^{52}$

\subsubsection{Opseg punomoći}

Opseg punomoći određuje stranka koja može punomoćnika ovlastiti za poduzimanje samo određene radnje ili svih radnji u postupku. ${ }^{53}$ Stranka koja je izdala punomoć ovlaštena je izmijeniti njen sadržaj, a time i opseg punomoćnikovih ovlaštenja. ${ }^{54}$ Opseg ovlaštenja opunomoćenika u upravnom sporu, kao i u parničnom postupku, ovisi o tome je li stranka dala punomoć odvjetniku ili osobi koja nije odvjetnik.

Ako je stranka izdala odvjetniku punomoć za vođenje postupka, a nije pobliže odredila ovlaštenja u punomoći, odvjetnik je ovlašten na temelju takve punomoći obavljati sve radnje u postupku, a odgovarajućom primjenom odredbi članka 95. ZPP-a u sporu, osobito podnijeti tužbu, povući je, sklopiti nagodbu, podnijeti pravni lijek i odreći se ili odustati od njega te zahtijevati izdavanje mjera osiguranja, stavljati zahtjev za ovrhu ili osiguranje i poduzimati potrebne radnje u postupku u povodu takva zahtjeva, prenijeti punomoć na drugog odvjetnika ili ovlastiti drugog odvjetnika na poduzimanje samo pojedinih radnji u postupku.

U parničnom postupku za podnošenje prijedloga za ponavljanje postupka odvjetniku je potrebna posebna punomoć, ako je od pravomoćnosti odluke proteklo više od šest mjeseci. Odvjetnički vježbenik bez položenoga pravosudnog ispita može zamjenjivati odvjetnika kod kojeg je zaposlen samo pred sudom prvoga

50 Čl. 90. ZPP-a.

51 Čl. 91. ZPP-a.

52 Čl. 66. st. 2. ZUS-a.

53 Čl. 94. ZPP-a.

54 Triva, Dika, op. cit. (bilj. 31.), str. 333. 
stupnja, u postupcima čija vrijednost predmeta spora nije veća od 50.000,00 kuna, a odvjetnički vježbenik s položenim pravosudnim ispitom može zamjenjivati odvjetnika bez ikakvih ograničenja.

Međutim, ako je odvjetniku privremeno obustavljeno pravo na obavljanje odvjetništva, zamjenjuje ga privremeni zamjenik kojem pripadaju sva prava koja ima odvjetnik kojeg zamjenjuje i bez punomoći stranaka. Isto kao i punomoćnik, privremeni zamjenik je već kod obavljanja prve radnje u postupku dužan sudu podnijeti rješenje o postavljanju za privremenog zamjenika. Ako odvjetnik prestane obavljati odvjetništvo, tada je preuzimatelj njegova ureda dužan bez posebne punomoći zastupati stranku najdulje šest mjeseci od dana kada je odvjetnik prestao obavljati odvjetništvo. Preuzimatelj ureda dužan je o tome, bez odgode, obavijestiti sud i stranku koju zastupa. ${ }^{55}$

Ako je stranka izdala punomoć osobi koja nije odvjetnik, a nije pobliže odredila ovlaštenja punomoćnika, tada punomoćnik koji nije odvjetnik može, na temelju takve punomoći, obavljati sve radnje u postupku, ali mu je uvijek, odgovarajućom primjenom odredbi članka 96. ZPP-a u sporu, potrebno izričito ovlaštenje za povlačenje tužbe, za sklapanje nagodbe, za odricanje ili odustanak od pravnog lijeka i za prenošenje punomoći na drugu osobu te za podnošenje izvanrednih pravnih lijekova. ${ }^{56}$

Dakle, zbog toga što nema stručne sposobnosti i zbog toga što za štetu ne odgovara po pravilima o pojačanoj odgovornosti, ovlaštenja na osnovi parnične punomoći punomoćnika koji nije odvjetnik znatno su uža od ovlaštenja odvjetnika. ${ }^{57}$

\subsubsection{Izdavanje punomoći i dostavljanje sudu}

Zakon o parničnom postupku propisuje da stranka izdaje punomoć pisano ili usmeno na zapisnik kod suda, a ako nije pismena ili nije u stanju potpisati se, stavit će na pisanu punomoć umjesto potpisa otisak kažiprsta. Ako se u tom slučaju punomoć izdaje osobi koja nije odvjetnik, potrebna je prisutnost dvojice svjedoka koji će se potpisati na punomoći. Ako posumnja u istinitost pisane punomoći, sud može rješenjem odrediti da se podnese ovjerena punomoć. ${ }^{58}$

U upravnom sporu opunomoćenik je već pri prvoj radnji dužan podnijeti sudu punomoć. Prema odredbama parničnog postupka, ako stranka pri prvoj radnji u parničnom postupku sudu ne dostavi punomoć za zastupanje, sud može dopustiti da radnje u postupku za stranku privremeno obavi osoba koja nije podnijela punomoć, ali će istovremeno narediti toj osobi da u naknadno određenom roku podnese punomoć ili odobrenje stranke za obavljanje parnične radnje. Dok ne protekne rok za podnošenje punomoći, sud će odgoditi donošenje odluke. Ako taj rok bezuspješno protekne, sud će nastaviti postupak, ne uzimajući u obzir radnje što ih je obavila osoba bez punomoći.

55 Čl. 95.a ZPP-a.

56 Čl. 96. ZPP-a.

57 Triva, Dika, op. cit. (bilj. 31.), str. 335.

58 Čl. 97. ZPP-a. 
Sud je dužan tijekom cijelog postupka paziti je li osoba koja se pojavljuje kao punomoćnik ovlaštena za zastupanje. Ako sud utvrdi da osoba koja se pojavljuje kao punomoćnik nije ovlaštena za zastupanje, ukinut će parnične radnje što ih je ta osoba poduzela ako te radnje nije stranka naknadno odobrila. ${ }^{59}$

\subsubsection{Prestanak punomoći}

Što se tiče prestanka punomoći, valja navesti da stranka može opozvati punomoć u svako vrijeme, a punomoćnik je može u svako vrijeme otkazati. Opozivanje odnosno otkaz punomoći mora se saopćiti sudu pred kojim se vodi postupak pisanim putem ili usmeno na zapisnik, a za protivnu stranku važi od trenutka kad joj je saopćen. Poslije otkaza punomoći punomoćnik je dužan još mjesec dana obavljati radnje za osobu koja mu je izdala punomoć ako je potrebno da od nje otkloni kakvu štetu koja bi u to vrijeme mogla nastati. ${ }^{60}$

Ako je punomoćniku dano ovlaštenje da može obavljati sve radnje u postupku, a stranka izgubi parničnu sposobnost, odnosno njezin zakonski zastupnik umre ili izgubi poslovnu sposobnost, ili ako zakonski zastupnik bude razriješen dužnosti, punomoćnik je ovlašten i nadalje poduzimati radnje u postupku, ali novi zakonski zastupnik može opozvati punomoć. U navedenim slučajevima punomoćniku koji nije odvjetnik uvijek prestaju ona ovlaštenja koja se u punomoći moraju izričito navesti. ${ }^{61}$

Ako je tužitelj ili zainteresirana osoba u sporu fizička osoba punomoć koju je ona izdala, prema pravilima parničnog postupka, prestaje smrću te osobe. Ako se radi o pravnoj osobi, punomoć prestaje prestankom pravne osobe. U slučaju stečaja pravne osobe, punomoć koju je izdao stečajni dužnik prestaje kad prema važećim propisima nastupe pravne posljedice otvaranja stečajnog postupka, ako zakonom nije drugačije određeno. Iznimno, punomoćnik je dužan još mjesec dana obavljati radnje u postupku ako je potrebno da od stranke otkloni štetu. ${ }^{62}$

\section{UMJESTO ZAKLJUČKA}

Stranke u sporu su tužitelj, tuženik i zainteresirana osoba.

Tužitelj i zainteresirana osoba mogu poduzimati radnje u sporu u granicama svoje postupovne sposobnosti. Oni nisu dužni sami poduzimati postupovne radnje, već to za njih može činiti ovlaštena osoba za zastupanje. Ako svojstvo tužitelja ima skupina osoba, tada za njih radnje u sporu poduzima zajednički predstavnik ili zajednički opunomoćenik. Za osobe koje nemaju postupovnu ni poslovnu sposobnost, radnje u sporu poduzimaju njihovi zakonski zastupnici. Na poslovnu

\begin{tabular}{ll}
\hline 59 & Čl. 98. ZPP-a. \\
60 & Čl. 99. ZPP-a. \\
61 & Čl. 100. ZPP-a. \\
62 & Čl. 101. ZPP-a.
\end{tabular} 
sposobnost fizičkih osoba na odgovarajući način se primjenjuju odredbe parničnog postupka.

Za tuženika, koji je uvijek javnopravno tijelo, radnje u sporu mogu poduzimati zaposlenici tuženika, a nakon izmjena i dopuna Zakona o upravnim sporovima od prosinca 2014. godine radnje u sporu za tuženika u propisanim slučajevima mogu poduzimati i službene osobe prvostupanjskog javnopravnog tijela. Tuženik nema ovlaštenje opunomoćiti neku osobu izvan kruga službenih osoba javnopravnog tijela za poduzimanje radnji u sporu za njega. Iznimno, ako je tuženo tijelo državne uprave ili drugo državno tijelo, njega može po punomoći čelnika zastupati državno odvjetništvo.

Osoba ovlaštena za zastupanje tužitelja i zainteresirane osobe može biti zakonski zastupnik, zajednički predstavnik ili opunomoćenik. Zakonski zastupnik zastupa postupovno nesposobnu osobu i svoje ovlasti crpi iz zakona ili iz akta nadležnog državnog tijela. Zajednički predstavnik predstavlja određenu skupinu koja ima položaj tužitelja u sporu, time da takva skupina može ovlastiti i zajedničkog opunomoćenika da je zastupa.

Tužitelj ili zainteresirana osoba ovlaštenje za zastupanje u sporu (punomoć) mogu u pravilu dati samo odvjetniku, uz propisane iznimke. Naime, nakon izmjena i dopuna Zakona o upravnim sporovima od prosinca 2014. godine, na valjanost zastupanja u upravnom sporu na odgovarajući način se primjenjuju odredbe kojima je uređeno zastupanje u parničnom postupku.

Dakle, pravila parničnog postupka primjenjuju se na poslovnu sposobnost fizičke osobe i na pitanja valjanosti zastupanja koja nisu uređena ZUS-om, ali na odgovarajući način, pritom uvažavajući strukturu i različitost upravnog spora. Možda bi ipak u narednim intervencijama u zakonsko uređenje pojedinih instituta u upravnom sporu trebalo težiti cjelovitijem uređenju upravnog spora jer odgovarajuća primjena pravila sličnog ali i različitog postupka ostavlja prostor za moguće dvojbe u tumačenju pojma „odgovarajuća“. Procesna pravila bi, po mišljenju autorice rada, trebala biti jasna i određena i u svemu uređivati postupak na koji se odnose. 


\section{Summary}

\section{PARTY REPRESENTATION IN ADMINISTRATIVE DISPUTE}

In this paper it is considered who can be a party in an administrative dispute. It is shown who can take action in behalf of a party in a procedure, also who is entitled to act for a plaintiff and for an interested person, as well as the question of the validity of party representation in administrative and civil procedure, accordingly applicable in administrative dispute.

Key words: administrative dispute, party, representation, civil procedure, procedural capacity, business capacity.

\section{Zusammenfassung}

\section{STELLVERTRETUNG DER PARTEI IM VERWALTUNGSSTREITVERFAHREN}

In dieser Arbeit setzt sich die Autorin mit der Frage auseinander, wer alles als eine Partei im Verwaltungsstreitverfahren teilnehmen kann. Es wird darauf hingewiesen, welche Personen im Namen der Parteien die Handlungen im Verfahren vornehmen können und welche Personen bewilligt für die Stellvertretung des Klägers und des Interessenten sind. Es wird auch über die Fragen der Stellvertretungsgültigkeit der Parteien im verwaltungsjuristischen Verfahren und im Prozessverfahren, der im Verwaltungsstreitfall auf angemessene Weise angewendet wird, diskutiert.

Schlüsselwörter: Verwaltungsstreitverfahren, Partei, Stellvertretung,

Prozessverfahren, Verfahrenskompetenz, Geschäftskompetenz. 


\section{Riassunto}

\section{LA RAPPRESENTANZA DELLA PARTE NEL GIUDIZIO AMMINISTRATIVO}

Nel presente lavoro si disamina chi possa partecipare in qualità di parte nel giudizio amministrativo. Si segnalano i soggetti che in nome delle parti possono intraprendere azioni nel procedimento e quali persone sono autorizzate a rappresentare il ricorrente e le persone interessate. Ancora, si sollevano le questioni concernenti la validità della rappresentanza delle parti nel contenzioso amministrativo ed in quello civile, applicabile nel giudizio amministrativo.

Parole chiave: contenzioso amministrativo, parte, rappresentanza, procedimento civile, capacità processuale, capacità d'agire. 